\title{
Effects of vegetation control treatments for release of Engelmann spruce from a mixed-shrub community in southern British Columbia - Year 15 results
}

\author{
by Philip G. Comeau and George J. Harper²
}

\begin{abstract}
Fifteen-year results from a study initiated in 1992 to compare the effectiveness of repeated cutting treatments with treatments involving single cutting or a single application of glyphosate herbicide are presented. While treatments resulted in significant improvements in diameter and height of planted spruce at ages 3 to 7 , these differences were no longer significant in year 15. All vegetation control treatments significantly increased survival in year 15 but did not significantly affect average spruce size. Despite apparent initial treatment effects on vegetation cover, the treatments applied in this study have had little lasting effect on non-crop vegetation.
\end{abstract}

Key words: vegetation management, herbicides, glyphosate, manual, interior spruce, mixed shrub complex, Interior Cedar Hemlock Zone.

\section{RÉSUMÉ}

Les résultats après 15 ans d'une étude amorcée en 1992 pour comparer l'efficacité des traitements de dégagement par coupes répétitives aux traitements de dégagement par coupe unique ou par application unique de l'herbicide glyphosate sont présentés dans cet article. Même si les traitements ont permis d’enregistrer des gains significatifs en termes de diamètre et de hauteur chez les semis d'épinette à la troisième et la septième année, ces différences nétaient plus significatives à la quinzième année. Tous les traitements de contrôle de la végétation ont permis un accroissement du taux de survie 15 ans plus tard mais n’ont eu aucun effet significatif sur la taille moyenne des épinettes. Malgré les effets apparents dès le début sur le couvert végétal, les traitements réalisés dans cette étude ont eu que peu d’effet durable sur la végétation non prévue pour faire partie d'une récolte.

Mots clés : contrôle de la végétation, herbicides, glyphosate, manuel, épinette de l'intérieur, association d’arbustes, forêt de thuya et de pruche de lintérieur

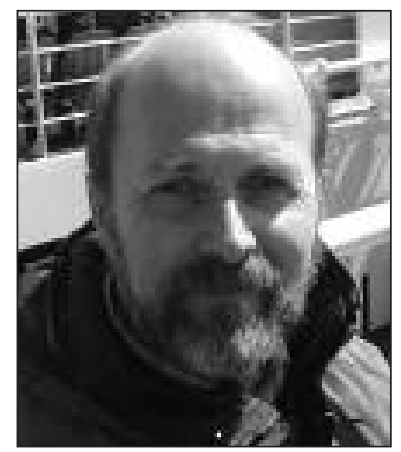

Philip G. Comeau

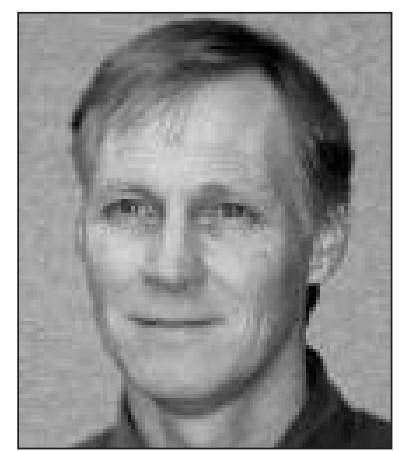

George J. Harper

\section{Introduction}

Vegetation management practices are recognized as being important to accelerating growth, achieving high yields and for maintaining certain types of forest structures in the landscape (Pitt et al. 2004, Pitt and Bell 2005, Wagner et al. 2006). However, some reports indicate substantial variation in the existence and magnitude of these growth gains (Comeau et al. 1999, Simard et al. 2001, Heineman et al. 2005).

Forest vegetation management activities have steadily increased across British Columbia (BC) over the last 30 years. Brushing activities in BC increased from 3000 ha in $1980 / 1981$ to about 60000 ha and a cost of approximately $\$ 25$ million in the $1989 / 1990$ fiscal year (BCMF 1991). In 1999/2000, 80843 ha of public forest land across the province was brushed, of which 46333 ha were treated manually (including manual and motor-manual cutting, bending and girdling). Manual brushing represented $62 \%$ of total brushing expenditures and $57 \%$ of the area brushed, at a cost of \$29 million (BCMF 2000). In southeastern BC (Nelson Forest Region) $88 \%$ of the area brushed in 2000 was treated manually and $10 \%$ chemically by ground applications. In $2002 / 2003$ the total hectares brushed provincially declined by approximately 29\% from 89526 ha in 2001/2002 and by another 25\% in 2003/2004 to 46952 ha. In 2006/2007, 40087 ha of public forest land were brushed, of which 21197 ha were manually treated (manual and motor-manual cutting, girdling, bending, clipping and mulching). In the Southern Interior Region, manual brushing accounted for $85 \%$ of all area treated. In the Northern Interior Region, manual brushing accounted for only $33 \%$ with ground and aerial herbicide application representing $63 \%$.

\footnotetext{
${ }^{1}$ University of Alberta, Dept. of Renewable Resources, 751 General Services Building, Edmonton, Alberta T6G 2H3. E-mail: Phil.Comeau@UAlberta.ca

${ }^{2}$ Research Branch, BC Ministry of Forests and Range, PO Box 9519 Stn Prov Govt, Victoria, British Columbia V8W 9C2.
} 
Manual brushing methods are socially acceptable, and they are subject to few, if any, environmental constraints. However, cutting treatments generally provide only shortterm relief from competing vegetation with control often lasting only for the balance of the growing season during which the treatment was applied (Miller 1985; Hart and Comeau 1992; Comeau et al. 1999, 2000). Several studies have found that a single manual treatment may be ineffective for controlling cover sufficiently to benefit seedling growth for more than a few years (Harper et al. 1997a, b; 1998; Whitehead and Harper 1998; Comeau et al. 2000; Simard et al. 2001; Heineman et al. 2005). Consequently, when manual brushing is being used to control vegetation around young conifer seedlings it may be necessary to repeat treatments on an annual or more frequent basis (Ehrentaut and Branter 1990, Comeau et al. 1999). For example, repeated cutting of competing species improved the 5-year height and stem diameter of Douglas-fir on the central coast of California (McDonald et al. 1994). Harper et al. (1998) report that at least 2 subsequent years of cutting are required to change the dry-warm ICH site from a paper birch- to a Douglas-fir-dominated stand. However, manual cutting treatments can cost up to 3 times more per hectare than aerially applied herbicide (Comeau et al. 2000, Dampier et al. 2006).

Season of treatment has been shown to influence the effectiveness of cutting treatments applied to young broadleaf trees (Bell et al. 1999) and some information suggests that early to midsummer treatments may be more effective for fireweed control than spring treatments (Hart and Comeau 1992). However, there have been no published studies examining effects of timing of single and repeated cutting treatments in mixed-shrub communities in southern BC.

Treatments using herbicides such as glyphosate (Vision ${ }^{\circ}$ ) generally provide vegetation control that can result in larger and more predictable growth responses. Glyphosate can provide control of a wide range of shrubs and herbs at fairly low rates whereas conifers have some resistance depending on their stage of development during the growing season. A single application of glyphosate during the first few years after planting has been shown to effectively improve conifer growth 9 to 20 years later in a wide range of plant communities in various ecosystems in British Columbia (Harper et al. 1997a, b; Whitehead and Harper 1998; Biring et al. 1999, 2000, 2001; Biring and Hays-Byl 2000; Simard et al. 2001; Harper et al. 2005; Boateng et al. 2006; Macadam and Kabzems 2006). The efficacy of glyphosate for vegetation control is due to its ability to suppress competing vegetation for more than one season.

This article presents 15-year results from a study initiated in 1991 to examine the effectiveness of various vegetation control treatments for controlling mixed-shrub communities and for increasing survival and growth of planted Engelmann spruce seedlings. Fifth-year results from this study were presented by Comeau et al. (2000) and 10-year results were presented by Biring et al. (2003). Yield forecasts for the treatments used in this study are presented by Harper et al. (2008).

The objectives of this paper are:

i) To compare the effects of single and repeated manual cutting treatments and a single glyphosate herbicide application on survival and growth of planted Engelmann spruce seedlings; ii) To discuss the potential longer term impacts of these treatments on yield, stand structure, and plant community diversity,

iii) Evaluate the usefulness of early (age 5) measurements of competition and tree response for predicting future (age 16) tree response.

\section{Methods}

The study was established at Soards Creek near Mica Dam in southeastern British Columbia in the fall of 1991. The study site is located in the very wet cool subzone variant of the Interior Cedar Hemlock (ICH) biogeoclimatic zone. It has a subhygric soil moisture regime, a rich soil nutrient and is classified as site series CwHw-Devils' Club-Lady Fern (Braumandl and Curran 1992). Aspect is $170^{\circ}$, slope ranges from $10 \%$ to $30 \%$, and elevation is $860 \mathrm{~m}$. The site was harvested in 1983/1984, broadcast burned in October 1984, and planted with Engelmann spruce (1+0 PSB 313) in June 1985. Five years after planting in 1990, the plantation was declared a failure, primarily due to intense vegetation competition. Prior to replanting, the site was mechanically prepared using a D6 cat with an excavator in August of 1990. The site was subsequently planted with 1-year-old (1+0 PSB 415B) Engelmann spruce seedlings at a $2.7 \mathrm{~m}$ espacement in June of 1991.

The study used a completely randomized design (CRD) consisting of 8 treatments replicated 3 times with treatments assigned to $30 \mathrm{~m} \times 30 \mathrm{~m}$ plots. The treatments comprised 6 combinations of spring, summer and annual repeated manual cutting, a single application of glyphosate, and an untreated control (Table 1). Within the central $20 \mathrm{~m} \times 20 \mathrm{~m}$ portion of each treatment plot, 20 Engelmann spruce seedlings were systematically selected and tagged for morphological measurements (e.g., height and diameter) and qualitative assessments (e.g., survival).

Manual cutting treatments were applied to the entire plot using hand tools (e.g., grass whips, machetes, and hand shears) to cut all vegetation including broadleaf species to within $5 \mathrm{~cm}$ of ground level. The herbicide glyphosate was applied at a rate of $2.1 \mathrm{~kg}$ a.e. ha ${ }^{-1}$ with a backpack sprayer on August 20, 1992. Approximately 0.6 litres of glyphosate product $\left(V_{i s i o n}{ }^{\circ}\right)$ in $10 \mathrm{~L}$ spray volume (with water) was used per treatment plot. Wind speed ranged from 0 to $2 \mathrm{~km} / \mathrm{hr}$, wind direction was $300^{\circ}$, relative humidity was $50 \%$ and air temperature was between $18^{\circ} \mathrm{C}$ and $20^{\circ} \mathrm{C}$ during the glyphosate application.

The selected Engelmann spruce seedlings were measured in years 0 (pre-treatment), 1, 2, 3, 4, 5, 7, 10, and 15. Measurements included total height, groundline diameter, diameter at $1.37 \mathrm{~m}$ height $(\mathrm{DBH})$, crown diameter, and height to the crown base. Vegetation was assessed for 20 seedlings in each treatment plot in 1992 and for 10 seedlings in each treatment plot in subsequent years. In the manual cutting treatment plots that included spring cutting (a, c, e) and the untreated control (h), pre-treatment vegetation assessments were completed on June 24th, 1992. Vegetation assessments were completed prior to summer brushing treatments in each of the 24 treatment plots in July of 1992. In subsequent years, vegetation assessments were completed during mid-summer prior to any cutting treatments being applied.

Data analyses were carried out with SAS ${ }^{\circ}$ software Version 9.1 (SAS Institute Inc., Cary NC). The experiment was 
Table 1. A description of the 8 treatments applied in the study (from Biring et al. 2003)

\begin{tabular}{|c|c|c|c|c|}
\hline Treatment & Common treatment name & $\begin{array}{c}\text { Treatment } \\
\text { symbol }\end{array}$ & $\begin{array}{c}\text { Year of } \\
\text { application }\end{array}$ & Dates of application \\
\hline $\begin{array}{l}\text { Spring (1992) } \\
\text { [1 cutting] }\end{array}$ & Single spring cutting & $\mathbf{a}$ & 1992 & June 25-26, 1992 \\
\hline $\begin{array}{l}\text { Summer }(1992) \\
{[1 \text { cutting] }}\end{array}$ & Single summer cutting & b & 1992 & July 25-28, 1992 \\
\hline $\begin{array}{l}\text { Spring }(1992+) \\
{\left[1 \times \mathrm{yr}^{-1} \text { for } 3 \mathrm{yr}\right]^{\mathrm{a}}}\end{array}$ & Repeated spring cutting for 3 years & c & 1992 + annually & $\begin{array}{l}\text { June } 25-26,1992 \text {; June } 15-17,1993 \text {; } \\
\text { June } 16,1994\end{array}$ \\
\hline $\begin{array}{l}\text { Summer }(1992+) \\
{\left[1 \times \mathrm{yr}^{-1} \text { for } 3 \mathrm{yr}\right]}\end{array}$ & Repeated summer cutting for 3 years & d & 1992 + annually & $\begin{array}{l}\text { July 25-28, 1992; July 20-22, 1993; } \\
\text { July 21, } 1994\end{array}$ \\
\hline $\begin{array}{l}\text { Spr+sum }(1992+) \\
{\left[2 \times \mathrm{yr}^{-1} \text { for } 3 \mathrm{yr}\right]^{\mathrm{b}}}\end{array}$ & $\begin{array}{l}\text { Spring and summer cutting } \\
\text { (in a year) for } 3 \text { years }\end{array}$ & e & 1992 + annually & $\begin{array}{l}\text { June } 25-26,1992 \text {; July } 25-28,1992 \text {; } \\
\text { June } 15-17,1993 \text {; July 20-22, 1993; } \\
\text { June 16, 1994; July 21, } 1994\end{array}$ \\
\hline $\begin{array}{l}\text { Spr+sum }(1993+) \\
{\left[2 \times \mathrm{yr}^{-1} \text { for } 2 \mathrm{yr}\right]}\end{array}$ & $\begin{array}{l}\text { Spring and summer cutting } \\
\text { (in a year) for } 2 \text { years }\end{array}$ & f & 1993 + annually & $\begin{array}{l}\text { June 15-17, 1993; July 20-22, 1993; } \\
\text { June 16, 1994; July 21, } 1994\end{array}$ \\
\hline $\begin{array}{l}\text { Glyphosate } \\
{\left[2.1 \mathrm{~kg} \text { a.e. } \mathrm{ha}^{-1}\right]}\end{array}$ & Single VISION ${ }^{\circledast}$ treatment & g & 1992 & August 20, 1992 \\
\hline Untreated control & Control & $\mathbf{h}$ & - & - \\
\hline
\end{tabular}

aSpring $1992+[1 \times$ yr- 1 for $3 \mathrm{yr}]=1$ cutting every year for 3 years

${ }^{\mathrm{b}} \mathrm{Spr}+\operatorname{sum}(1992+)$ [ $2 \times 3 \mathrm{yr}-1$ for $\left.3 \mathrm{yr}\right]=2$ cuttings every year for 3 years.

analysed as a single factor, completely randomised design with 8 treatments and 3 replications. Due to significant $(\mathrm{p} \leq$ $0.05)$ pre-treatment differences in seedling height and groundline diameter, analysis of covariance (ANCOVA) was used to analyze the data for 1992 to 2006 using 1991 values as covariates. Fisher's Least-Significant-Difference (LSD) test was used to make comparisons among treatment means. Polynomial contrasts were also used to make comparisons between treatments (Table 2). Coefficients for planned polynomial contrasts between treatments can be found in Biring et al. (2003). Logistic regression was used to test for treatment effects on seedling survival.

\section{Results}

In 2006, 16 growing seasons after planting (and 15 growing seasons after the start of the experiment), cover of conifers was significantly higher in the glyphosate and some of the other repeated cutting treatments (d and $\mathrm{f}$ ) compared to the untreated control (Table 2). This is a result of greater conifer crown expansion and higher survival of both planted and natural regeneration in treated plots. Biring et al. (2003) reported that spruce densities in most treatments exceeded original planting densities, indicating natural regeneration. Spruce densities at age 10 were generally much greater in treated plots than in untreated. Densities of other conifers did not differ between treatments in year 10. While total vegetation cover was highest in the untreated, differences between treatments are non-significant, as are differences in cover of other layers. This contrasts with the significant differences in cover detected in years 1, 2 and 3 of the study (Fig. 1).

Table 3 presents treatment means for the $15^{\text {th }}$-year posttreatment measurement of the tagged spruce and Table 4 provides the results from the various planned polynomial contrasts. Tests for overall treatment effect ( $p$-value) indicated that $\%$ survival was significantly influenced by the various treatments. Survival over the 16 years averages $56.7 \%$ in the untreated control. Survival results mirror those found in year 10 (Biring et al. 2003) where significantly higher survival was found in the manual cutting (single and repeated) and glyphosate treatments when compared to the untreated control. In addition, repeated cutting and the single glyphosate treatments resulted in improvements in survival over only 1 year of treatment. The untreated control and single summer cutting treatments were the only treatments where survival declined after the $10^{\text {th }}$ year (Fig. 2).

While there are some apparent treatment differences in height (Fig. 3) and diameter growth (Table 3), no significant differences were noted in the 2006 treatment means for tagged spruce total height, height increment, $\mathrm{DBH}$, diameter increment, stem volume (STV $=\mathrm{m}^{3} /$ tree $\left.^{\star} 100\right)$ ) or height: diameter ratio (HDR; height and diameter increment results not shown). The glyphosate treatment did not result in significant changes in average height, diameter increment or DBH of surviving trees in 2006 compared to the other treatments.

Given the substantial interest in making decisions about the future growth of plots from survey data we present a simple illustration of relationships between earlier measurements and tree height and DBH in 2006. As Fig. 4 shows, relationships between size at age 16 (2006) and size in preceding years becomes stronger with age. The significant linear relationships indicate the importance of tree size to future development and the need to ensure early vigorous growth to optimize plantation performance.

\section{Discussion}

\section{Plant community impacts}

The lack of significant differences in cover indicates that treatments have had little impact on long-term vegetation develop- 
Table 2. Effects of treatment on vegetation cover (15 ${ }^{\text {th }}$ year data)

\begin{tabular}{|c|c|c|c|c|c|c|c|c|}
\hline \multirow[b]{2}{*}{ Treatment } & & \multicolumn{7}{|c|}{ Percent cover } \\
\hline & & Total & CONF & BRDL & TSHR & LSHR & HERB & GRASS \\
\hline $\begin{array}{l}\text { Spring (1992) } \\
\text { [1 cutting] }\end{array}$ & $\mathbf{a}$ & $110 \pm 4.2^{\mathrm{a}}$ & $28 \pm 2.2^{b c}$ & $4 \pm 1.3$ & $11 \pm 3$ & $29 \pm 2.5$ & $35 \pm 3.4$ & $3 \pm 0.8$ \\
\hline $\begin{array}{l}\text { Summer }(1992) \\
{[1 \text { cutting] }}\end{array}$ & b & $114 \pm 3$ & $26 \pm 2.7^{b c}$ & $11 \pm 2.9$ & $13 \pm 3.3$ & $32 \pm 3.2$ & $28 \pm 3.5$ & $4 \pm 1.2$ \\
\hline $\begin{array}{l}\text { Spring }(1992+) \\
{\left[1 \times \mathrm{yr}^{-1} \text { for } 3 \mathrm{yr}\right]^{\mathrm{b}}}\end{array}$ & c & $108 \pm 3.1$ & $27 \pm 1.6^{b c}$ & $10 \pm 2.8$ & $6 \pm 1.4$ & $22 \pm 2.9$ & $41 \pm 2.9$ & $2 \pm 0.5$ \\
\hline $\begin{array}{l}\text { Summer }(1992+) \\
{\left[1 \times \mathrm{yr}^{-1} \text { for } 3 \mathrm{yr}\right]}\end{array}$ & d & $115 \pm 3.2$ & $30 \pm 2.2^{\mathrm{ab}}$ & $10 \pm 1.9$ & $19 \pm 4.1$ & $25 \pm 2.7$ & $25 \pm 2.8$ & $6 \pm 1.3$ \\
\hline $\begin{array}{l}\text { Spr+sum }(1992+) \\
{\left[2 \times \mathrm{yr}^{-1} \text { for } 3 \mathrm{yr}\right]^{\mathrm{b}}}\end{array}$ & e & $108 \pm 3.8$ & $30 \pm 1.6^{b c}$ & $9 \pm 2.1$ & $9 \pm 2.3$ & $29 \pm 3$ & $26 \pm 2.8$ & $4 \pm 1$ \\
\hline $\begin{array}{l}\text { Spr }+\operatorname{sum}(1993+) \\
{\left[2 \times \mathrm{yr}^{-1} \text { for } 2 \mathrm{yr}\right]}\end{array}$ & f & $116 \pm 3.1$ & $31 \pm 2.4^{\mathrm{ab}}$ & $7 \pm 2.1$ & $13 \pm 2.9$ & $32 \pm 3.6$ & $28 \pm 3.8$ & $5 \pm 1.6$ \\
\hline $\begin{array}{l}\text { Glyphosate } \\
{\left[2.1 \mathrm{~kg} \text { a.e. } \mathrm{ha}^{-1}\right]}\end{array}$ & $\mathbf{g}$ & $101 \pm 3.4$ & $39 \pm 3.4^{\mathrm{a}}$ & $3 \pm 0.7$ & $7 \pm 2.9$ & $13 \pm 2.1$ & $29 \pm 3$ & $11 \pm 3.2$ \\
\hline Untreated control & $\mathbf{h}$ & $131 \pm 3.7$ & $21 \pm 1.8^{c}$ & $12 \pm 3.3$ & $16 \pm 3.2$ & $38 \pm 3$ & $37 \pm 4$ & $7 \pm 1.9$ \\
\hline$p$-value & & 0.0741 & 0.0344 & 0.7544 & 0.6808 & 0.1307 & 0.1529 & 0.6670 \\
\hline
\end{tabular}

CONF = Coniferous; BRDL = Broadleaves; TSHR = Tall shrubs; LSHR = Low shrubs; HERB = Herbs; GRAS = Grasses, sedges and rushes Treatment means \pm standard error

$\mathrm{b}_{1} \times=1$ cutting

$c_{2} \times 2$ cuttings

Letters indicate significant differences within columns among treatments detected using Fisher's Least-Significant-Difference Test at $\alpha=0.05$.

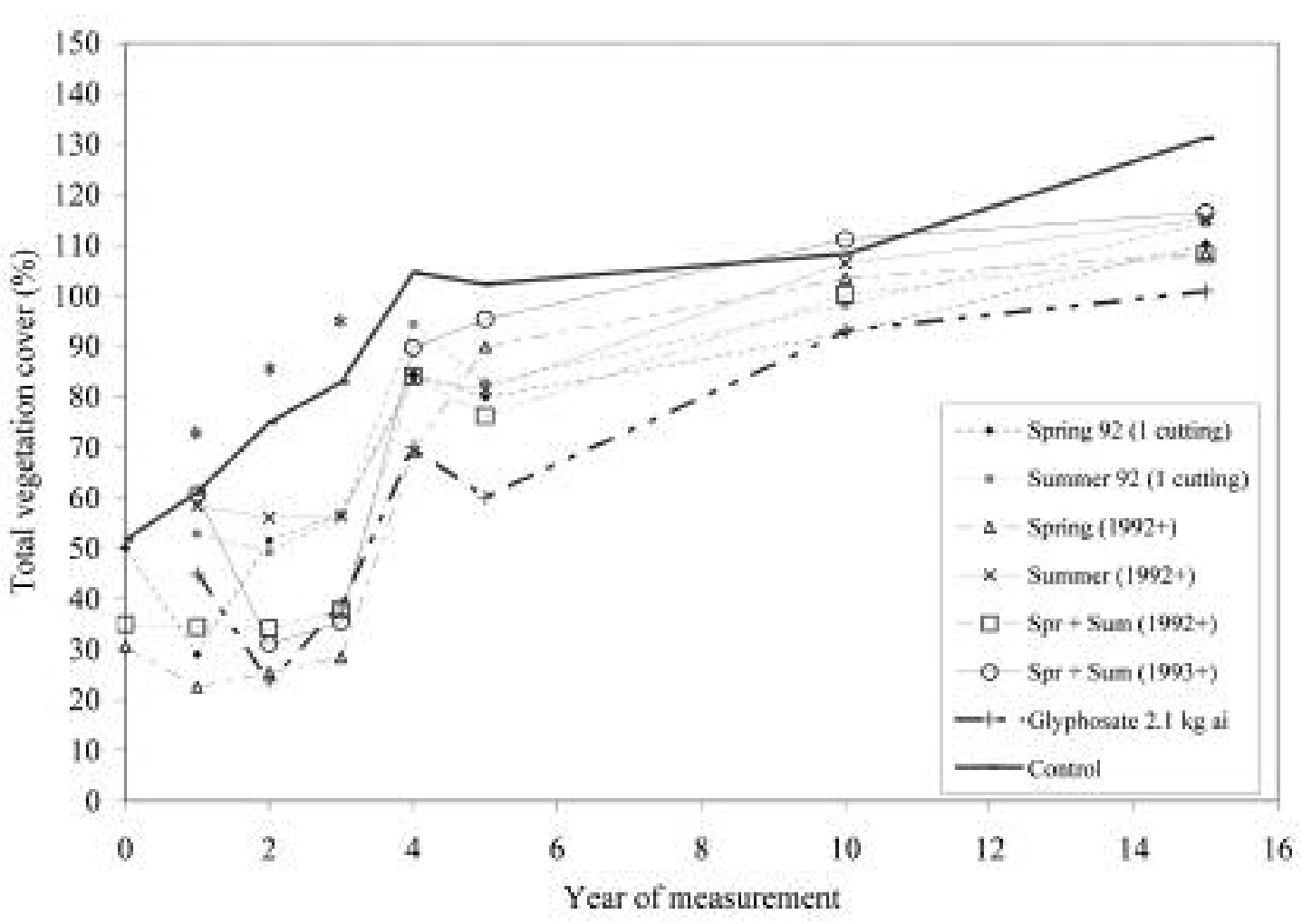

Fig. 1. Treatment total vegetation percent cover over year of measurement. Asterisk indicates years where significant treatment effect found ( $\mathrm{p} \leq$ 0.05). 
Table 3. Treatment means for tagged spruce $\left(15^{\text {th }}\right.$ year data)

\begin{tabular}{|c|c|c|c|c|c|c|}
\hline Treatment & & $\begin{array}{c}\text { SURVIVAL } \\
(\%)\end{array}$ & $\begin{array}{l}\mathrm{HT} \\
(\mathrm{cm})\end{array}$ & $\begin{array}{l}\mathrm{DBH} \\
(\mathrm{cm})\end{array}$ & $\begin{array}{c}\text { STV } \\
\left(\mathbf{m}^{3} / \text { tree }^{\star} 100\right)\end{array}$ & HDR \\
\hline $\begin{array}{l}\text { Spring }(1992) \\
{[1 \text { cutting }]}\end{array}$ & $\mathbf{a}$ & 80 & $521 \pm 24^{\mathrm{a}}$ & $8.7 \pm 0.5$ & $1.409 \pm 0.170$ & $29.0 \pm 1.1$ \\
\hline $\begin{array}{l}\text { Summer }(1992) \\
{[1 \text { cutting] }}\end{array}$ & $\mathbf{b}$ & 80 & $464 \pm 22$ & $7.8 \pm 0.4$ & $0.976 \pm 0.114$ & $29.3 \pm 1.3$ \\
\hline $\begin{array}{l}\text { Spring }(1992+) \\
{\left[1 \times \mathrm{yr}^{-1} \text { for } 3 \mathrm{yr}\right]}\end{array}$ & c & 100 & $496 \pm 24$ & $8.9 \pm 0.4$ & $1.381 \pm 0.146$ & $27.5 \pm 1.1$ \\
\hline $\begin{array}{l}\text { Summer }(1992+) \\
{\left[1 \times \mathrm{yr}^{-1} \text { for } 3 \mathrm{yr}\right]}\end{array}$ & d & 91.7 & $556 \pm 23$ & $9.4 \pm 0.4$ & $1.634 \pm 0.153$ & $30.0 \pm 1.0$ \\
\hline $\begin{array}{l}\text { Spr+sum }(1992+) \\
{\left[2 \times \mathrm{yr}^{-1} \text { for } 3 \mathrm{yr}\right]}\end{array}$ & e & 95 & $573 \pm 19$ & $9.8 \pm 0.4$ & $1.743 \pm 0.170$ & $28.6 \pm 0.5$ \\
\hline $\begin{array}{l}\text { Spr+sum }(1993+) \\
{\left[2 \times \mathrm{yr}^{-1} \text { for } 2 \mathrm{yr}\right]}\end{array}$ & $\mathbf{f}$ & 86.7 & $578 \pm 20$ & $9.8 \pm 0.4$ & $1.762 \pm 0.156$ & $29.1 \pm 1.3$ \\
\hline $\begin{array}{l}\text { Glyphosate } \\
{\left[2.1 \mathrm{~kg} \text { a.e. } \mathrm{ha}^{-1}\right]}\end{array}$ & $\mathbf{g}$ & 96.7 & $547 \pm 19$ & $9.0 \pm 0.4$ & $1.446 \pm 0.135$ & $29.2 \pm 0.7$ \\
\hline Control & $\mathbf{h}$ & 56.7 & $519 \pm 20$ & $9.1 \pm 0.4$ & $1.316 \pm 0.162$ & $27.9 \pm 1.0$ \\
\hline$p$-value & & $<0.0001$ & 0.6014 & 0.7294 & 0.5690 & 0.7722 \\
\hline
\end{tabular}

SURV = \% Survival; HT = Spruce height $(\mathrm{cm}) ; \mathrm{DBH}=$ Diameter breast height $(\mathrm{cm}) ; \mathrm{STV}=$ stem volume $\left(\mathrm{m}^{3} /\right.$ tree $\left.^{\star} 100\right) ; \mathrm{HDR}=\mathrm{Height}-\mathrm{to}-$ diameter breast height ratio aTreatment means \pm standard error.

Table 4. P-values for test of treatment effect and planned polynomial contrasts between treatments (15 $5^{\text {th }}$ year data)

\begin{tabular}{|c|c|c|c|c|c|}
\hline Contrast & SURV & HT & DBH & STV & HDR \\
\hline Single cutting vs. untreated control & $0.001^{*}$ & 0.679 & 0.624 & 0.768 & 0.394 \\
\hline Single cutting vs. repeated cutting (all) & $<0.001$ & 0.499 & 0.437 & 0.461 & 0.688 \\
\hline Single cutting vs. repeated cutting (spring) & $<0.001$ & 0.710 & 0.864 & 0.729 & 0.295 \\
\hline Single cutting vs. repeated cutting (summer) & 0.063 & 0.194 & 0.213 & 0.176 & 0.644 \\
\hline Repeated (all-once) vs. untreated control & $<0.001$ & 0.962 & 0.965 & 0.819 & 0.558 \\
\hline Repeated spring cutting vs. untreated control & $<0.001$ & 0.755 & 0.821 & 0.920 & 0.799 \\
\hline Repeated summer cutting vs. untreated control & $<0.001$ & 0.697 & 0.761 & 0.613 & 0.196 \\
\hline Repeated cutting $(2 \times 1992+)$ vs. untreated control & $<0.001$ & 0.439 & 0.505 & 0.303 & 0.654 \\
\hline Single spring cutting vs. single summer cutting & 1.000 & 0.389 & 0.423 & 0.326 & 0.830 \\
\hline Repeated spring cutting vs. repeated summer cutting & 0.008 & 0.410 & 0.534 & 0.473 & 0.072 \\
\hline Repeated annual cutting vs. repeated twice annually cutting & 0.171 & 0.320 & 0.394 & 0.263 & 0.915 \\
\hline Repeated twice annually 1992 vs. repeated twice annually 1993 & 0.108 & 0.998 & 0.960 & 0.864 & 0.738 \\
\hline Glyphosate vs. single cutting & 0.001 & 0.251 & 0.527 & 0.444 & 0.955 \\
\hline Glyphosate vs. repeated cutting annually & 0.329 & 0.530 & 0.973 & 0.876 & 0.686 \\
\hline Glyphosate vs. repeated cutting twice annually & 0.647 & 0.742 & 0.435 & 0.395 & 0.659 \\
\hline Glyphosate vs. untreated control & $<0.001$ & 0.614 & 0.987 & 0.747 & 0.406 \\
\hline Overall Treatment effect (ANCOVA) & $<0.0001$ & 0.6014 & 0.7294 & 0.569 & 0.7376 \\
\hline
\end{tabular}

Critical p-value $=\alpha /$ number of contrasts $=0.05 / 16=0.0031 ; *$ bold values indicate significant differences for the contrast; SURV $=\%$ Survival; HT $=$ Spruce height $(\mathrm{cm})$; $\mathrm{DBH}=$ Diameter breast height $(\mathrm{cm}) ; \mathrm{STV}=$ stem volume $\left(\mathrm{m}^{3} /\right.$ tree $\left.{ }^{\star} 100\right) ; \mathrm{HDR}=$ Height-to-diameter breast height ratio; Seedling survival treatment effect p-values are based on chi-square $\left(\chi^{2}\right)$ test and all other treatment effect p-values are based on Analysis of Covariance (ANCOVA); Bold values indicate significant differences for the treatment effect.

ment while they have favoured some increase in spruce cover. At age 10 on this site, no effects on species richness and diversity were evident (Biring et al. 2003). While broadleaf cover was significantly lower in many of the treatments compared to the control at age 10, this was not detected at age 16 . However, at age 16 , broadleaf cover was lower $(3 \%)$ in the glyphosate treatment compared to the untreated $(12 \%)$. While differences in conifer cover were evident but not significant at age 10, the glyphosate and some of the repeated cutting treatments have significant increases in conifer cover at age 16.

The observed lack of long-term effects of either repeated cutting or a single application of glyphosate herbicide on plant species richness and diversity (other than accelerating development of conifer cover) is consistent with the findings 


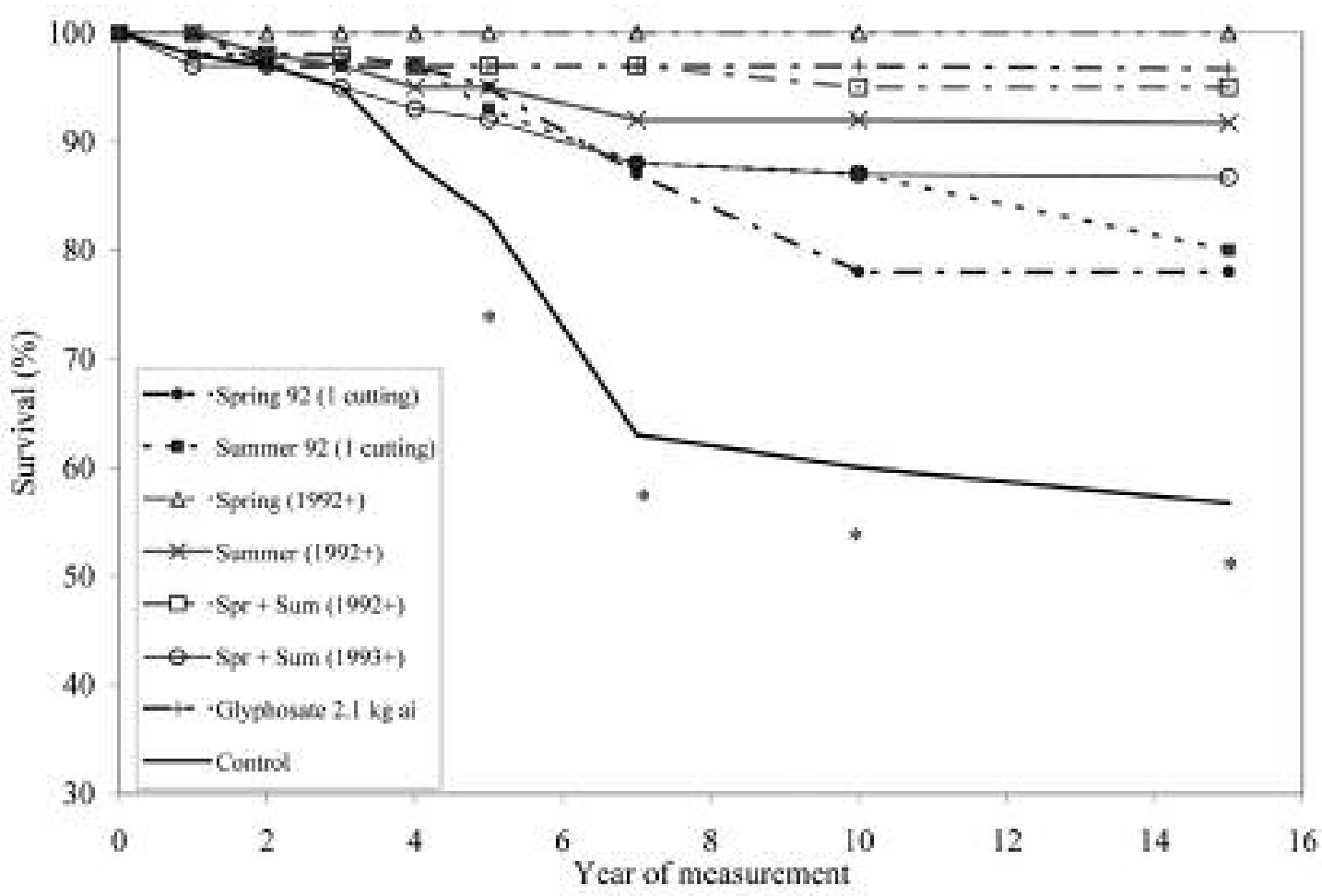

Fig. 2. Spruce percent survival by treatment over the 15 year measurement period. Asterisk indicates years where significant treatment effect found (chi-square test $p<0.05$ ).

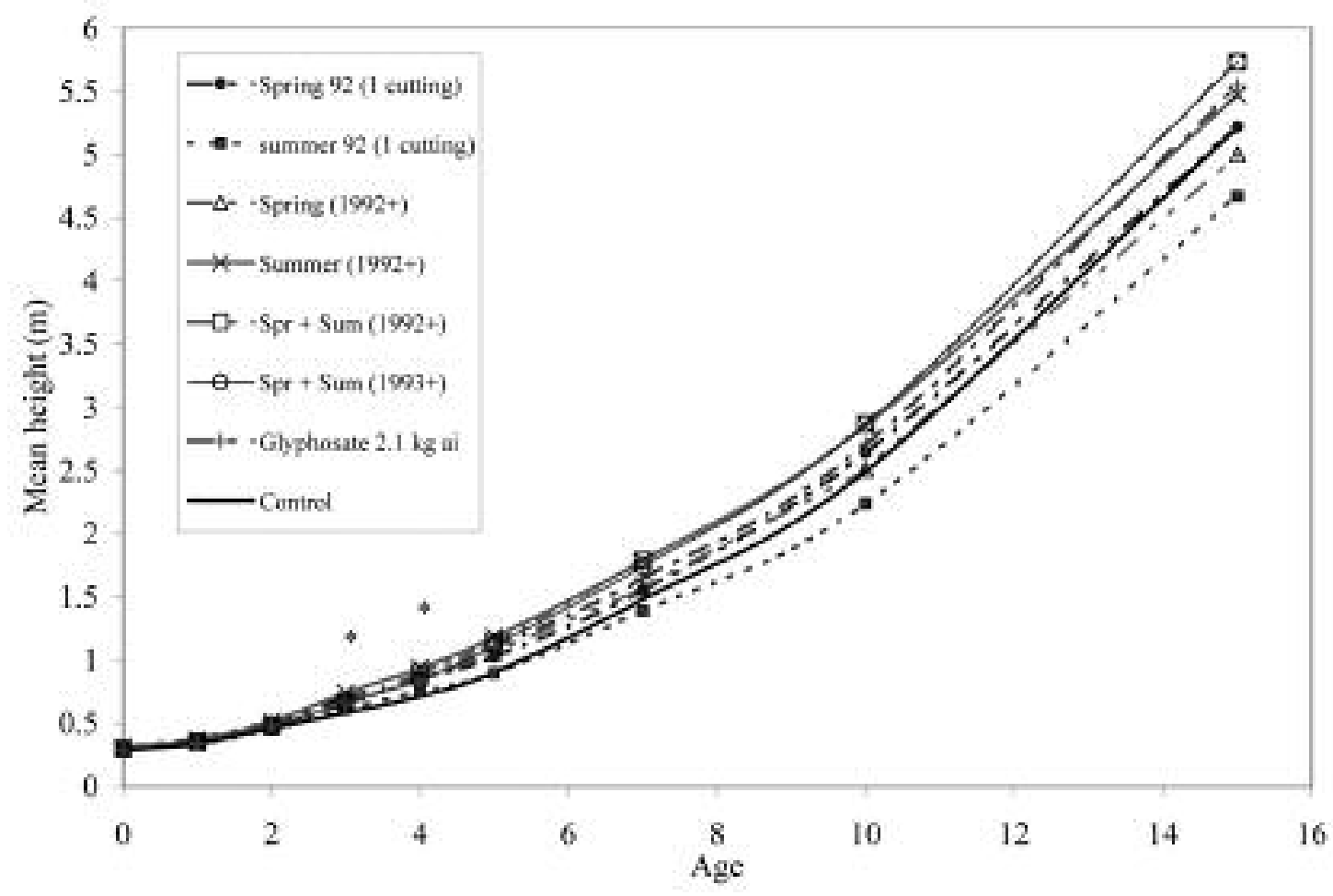

Fig. 3. Engelmann spruce mean height by treatment over the 15 year post treatment period. Asterisk indicates years where a significant treatment effect found (p value $\leq 0.05$ for overall treatment effect). 

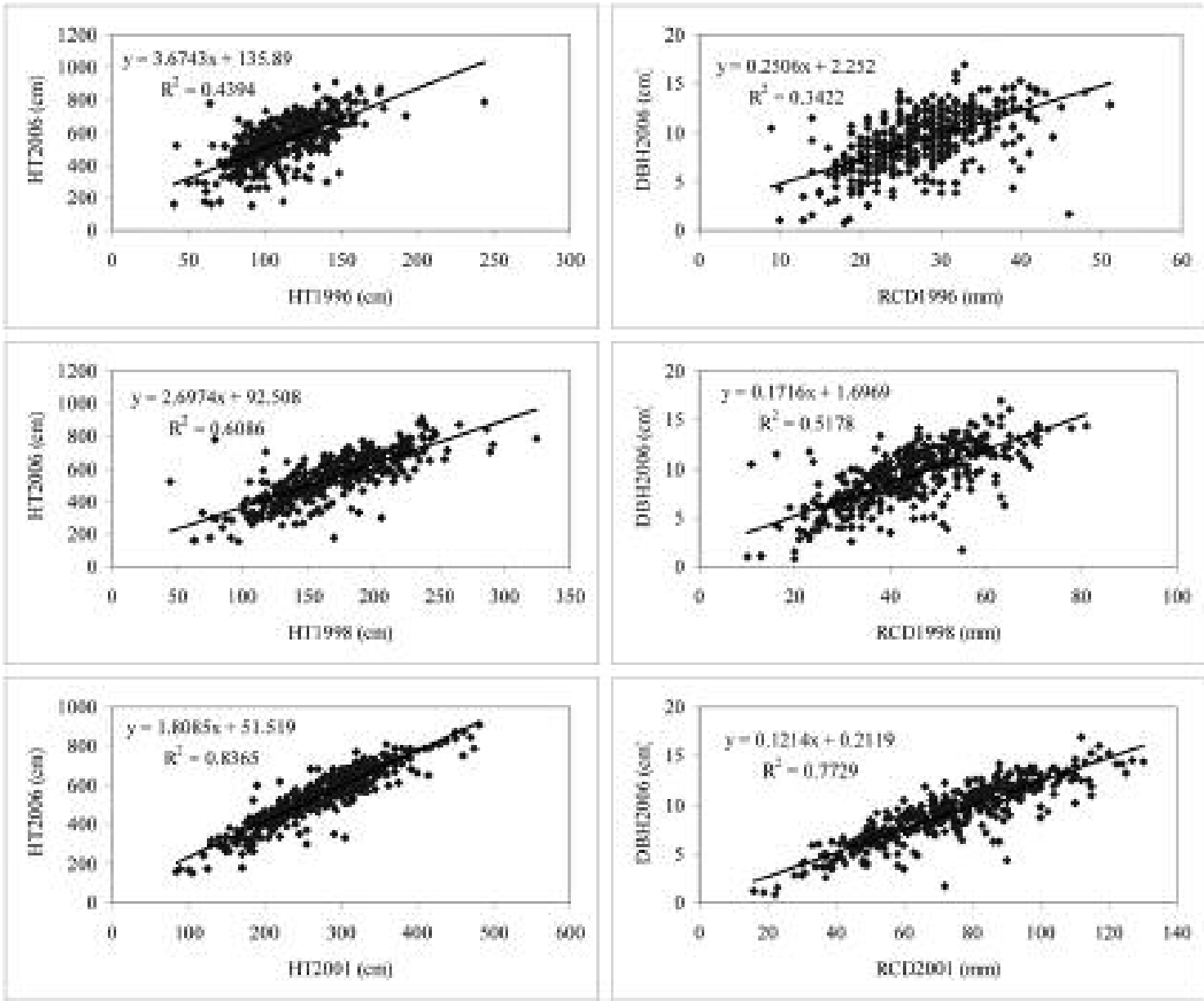

Fig. 4. Relationships between tree size in 2006 and tree size in 1996 (year 5), 1998 (year 7) and 2001 (year 10) for both height and diameter. (Sample size $=393$ trees).

of several other studies, including results reported in a similar mixed-shrub community (Simard et al. 2001) and other vegetation communities (Newton et al. 1992; McDonald et al. 1994; Harper et al. 1997a, b; Sullivan et al. 1998; Biring et al. 1999, 2000, 2001; Biring and Hays-Byl 2000; Boateng et al. 2000; Lindgren and Sullivan 2001; Haeussler et al. 2002).

Black cottonwood and paper birch generally resprout vigorously following manual cutting (Haeussler et al. 1990). However, in this study there was no increase in broadleaf percent cover following either single or repeated cutting treatments. This may be the result of rapid development of other vegetation layers following treatment or other factors that may have limited broadleaf regrowth.

\section{Spruce survival}

Mixed-shrub complex vegetation can seriously reduce survival and growth of planted conifers, particularly on wetter sites in the interior of British Columbia. Based on survival data available for a limited number of replicated trials in British Columbia, Comeau et al. (1999) concluded that improvements in seedling survival through brushing during the first 5 years after planting should be expected on mixed- shrub sites where vegetation competition is very intense. Although initial survival was unaffected by treatment in this study, longer-term survival of planted spruce was improved significantly by treatment. Both manual cutting (single and repeated) and glyphosate treatments significantly improved survival over that in the untreated control at age 16. Repeated cutting also resulted in better survival than only a single cutting. McMinn (1982) also reports a significant improvement in survival of white spruce 10 years after manual brushing of a mixed-shrub community. Other studies in the mixed-shrub complex (Simard et al. 2001, Heineman et al. 2005) report that a single manual cutting treatment did not improve hybrid spruce survival.

Much of the mortality observed in our study occurred in years 4,5 , and 6 and differ from the widely held belief that mortality usually occurs during the first few years after planting. This may have been related to the delay in the development of vegetation cover, with maximum cover and competition levels being reached in the untreated plots in years 4 and 5 (Comeau et al. 2000). Delayed vegetation development was likely the result of the blading treatment applied to much of the study site in 1990. Repeated cutting and application of 
glyphosate resulted in a small but significant improvement in 16-year survival over that provided by cutting only once. The repeated cutting provided similar results to a single application of glyphosate. In the absence of the blading treatment, more dramatic differences between treatments in survival and growth, and earlier onset of mortality would be expected. However, poor survival can also result from problems with planting stock (poor stock, storage and handling problems, poor planting), planting delay, microclimatic or microsite issues (frost, flooding, drought), browsing, insects, and other problems. Prior to 1985, problems with stock quality and planting delays were common in the BC Interior.

\section{Spruce growth}

Several studies have documented both short-term and longterm increases in conifer diameter growth after manual cutting or herbicide applications (e.g., Sutton 1995; Harper et al. 1997a, b; Biring et al. 1999, 2000, 2001; Biring and Hays-Byl 2000; Simard et al. 2001; Fu et al. 2007; Rose and Ketchum 2003). In our study treated spruce seedlings exhibited a significant increase in groundline diameter from the end of the $2^{\text {nd }}$ growing season after treatment until year 7. Similarly, increases in spruce height growth were observed in the $3^{\text {rd }}$ and $4^{\text {th }}$ years after treatment. However, the average diameter and height of surviving spruce did not differ between the vegetation control treatments or the untreated control at age 16 . Continued mortality of suppressed seedlings after year 7 is a probable cause of lack of treatment differences in the $10^{\text {th }}$ and $15^{\text {th }}$ years after treatment, with mortality of small seedlings likely resulting in an upward shift in mean height and diameter for the untreated plots.

Simard et al. (2001) reported that a single manual cutting was not effective in controlling mixed shrub vegetation for more than one year on $3 \mathrm{ICH} / \mathrm{ESSF}$ sites in the southern interior of BC. A single manual cutting did not improve planted spruce survival; however, improvement in seedling diameter and a decrease in height:diameter ratio was noted 3 years post-brushing. Heineman et al. (2005) also found no effect of a single manual cutting on the 5-year survival or growth of planted hybrid spruce from 19 sites located in the ICH and ESSF. However, similar manual cutting treatments applied to ericaceous shrub-dominated vegetation on highelevation ESSF sites in southern BC was found to improve survival and diameter growth of Engelmann spruce seedlings 3 years to 5 years post-brushing but not after 10 years (Heineman et al. 2007). These observations, and those from our study, serve to illustrate the potential effects of vegetation development, seedling development, and competition intensity on the results of applied vegetation management treatments. They also indicate the substantial variation in potential responses due to influences of site and past management practices, which necessitates site-specific prescriptions.

While cutting and glyphosate treatments resulted in significant improvements in survival at age 16, treatment effects on average spruce volume were not statistically significant. The substantial variability between plots and the small number of replications used in this study provided poor statistical power and a lack of statistical evidence to support apparent treatment differences. TASS simulations of the treatments indicated that the glyphosate and repeated cutting treatments may shorten physical rotation age by 7 years (a 14\% reduction in rotation length), increase culmination MAI by between $11 \%$ and $12 \%$, and increase merchantable volume at age 42 by $18 \%$ compared to the untreated control (Harper et al. 2008). Since these estimates do not include consideration of the small component of broadleaves present on this site (models for mixed-species stands are not yet available for this region), they are likely to slightly overstate differences in total (conifer plus broadleaf) yield.

It is not surprising that relationships between tree size at younger ages and size at age 16 become weaker as the time between measurements increases. While age 16 values appear to be strongly related to age 10 values, the fact that correlations become weaker with increasing time between measurements suggests a need for caution in trying to estimate longterm future trends from current tree size. However, given the change in size and position of trees relative to competing vegetation it may not be unreasonable to expect that measurements taken when trees have grown to a stage when they are no longer being influenced by the competing vegetation may be effective as predictors of future stocking and growth. Care must still be exercised in extrapolating results from age 16 to later years.

\section{Treatment costs}

While this study demonstrated that repeated cutting could be highly effective for vegetation control, several other issues such as cost and potential damage to crop seedlings must be considered. Comeau et al. (2000) discussed the cost implications of choosing a single manual cutting, repeated manual cutting or glyphosate treatments. Based on 2000 statistics for the Nelson Forest Region a single manual cutting treatment using hand tools would cost $\$ 545$ per ha or $\$ 617$ per ha using motorised brushsaws. To manually treat the same site 3 times using either hand tools or brushsaws would cost 3 times more; and, to apply glyphosate herbicide using backpack sprayers would be $\$ 743$ per ha. While no data are available for aerial applications in the local area for year 2000, the average cost of aerial herbicide application for the province of British Columbia in 2000 was $\$ 293$ per ha. Cost-effectiveness plays a key role in evaluating treatment options. This study demonstrated that the effect of repeated cutting in 3 successive years could have an effect on vegetation control and subsequent conifer growth equivalent to that obtained from a single application of glyphosate herbicide. An option for reducing costs on some sites could be to brush only a specified radius around each crop seedling.

Potential for environmental impacts must also be considered during treatment selection. Glyphosate herbicide has low toxicity to mammals and birds, does not bioaccummulate, is immobilized in most soils, and degrades rapidly in forest soils (Tatum 2004). As results from this study and others indicate, a single application of this herbicide appears to generally have only short-term effects on plant communities. While manual cutting tools pose little environmental hazard beyond risk of damage to crop seedlings and effects on community development, motorized brushsaws are frequently used for cutting treatments in woody and mixed vegetation complexes. Risks of gasoline and oil spillage, and exhaust emissions from brushsaws do pose potential environmental and health risks (Dubeau et al. 2003). Regulated use, low rates of application, requirements for untreated buffers, monitor- 
ing, and requirements for applicator certification and training for the use of herbicides for forestry in Canada are important components in minimizing environmental risks from forestry herbicide use. Potential effects of mechanical site preparation on soils and site productivity should also be considered when developing prescriptions.

\section{Conclusions}

15-year data from this study indicates that repeated cutting treatments can result in similar improvements in survival responses to those provided by a single application of glyphosate herbicide. At this site, vegetation control treatments did not result in significant improvements in average height or diameter of spruce at age 16. However, yield increases are anticipated from these treatments from improved survival. Despite apparent initial effects on vegetation cover, the treatments applied in this study have had little detectable effect on non-crop vegetation at age 16 . Periodic remeasurement of this and other similar studies is important to documenting the yield implications of vegetation management treatments. We recommend that future studies of this nature should focus on fewer treatments with more replication and strive for less uncontrolled variation in site and vegetation characteristics.

\section{Acknowledgements}

We gratefully acknowledge funding provided by the BC Forest Investment Account - Forest Science Program. We are also grateful to Balvinder Biring, Peter Fielder, Wendy Bergerud, Susan Humphries, Meghan O'Neill, Kurt Huetmeyer, Barb Wadey and Peter Gribbon for assistance with this project.

\section{References}

Bell, F.W., D.G. Pitt, A.E. Morneault and S.M. Pickering. 1999. Response of immature trembling aspen to season and height of cut. Northern J. Appl. Forestry 16: 108-114.

Biring B.S., P.G. Comeau and P. Fielder. 2003. Long-term effects of vegetation control treatments for release of Engelmann spruce from a mixed-shrub community in Southern British Columbia. Ann. For. Sci 60: 681-690.

Biring B.S. and W.J. Hays-Byl. 2000. Ten-year conifer and vegetation responses to glyphosate treatment in the SBSdw3. BC Min. For., Res. Br., Exten. Note 48. Victoria, BC.

Biring B.S., W.J. Hays-Byl and S.E. Hoyles. 1999. Twelve-year conifer and vegetation responses to discing and glyphosate treatments on a BWBSmw backlog site. BC Min. For., Res. Br., Work. Pap. 43. Victoria, BC

Biring B.S., H.K. Yearsley and W.J. Hays-Byl. 2000. Pinchi lake operational herbicide monitoring: 10-year conifer and vegetation responses in the SBSdw3. BC Min. of For., Res. Br. Exten. Note 46. Victoria, BC

Biring B.S., H.K. Yearsley, and W.J. Hays-Byl. 2001. Ten-year responses of white spruce and associated vegetation after glyphosate treatment at Tsilcoh River. BC Min. of For., Res. Br., Exten. Note 55. Victoria, BC.

Boateng J. O., S. Haeussler, and L. Bedford. 2000. Boreal plant community diversity 10 years after glyphosate treatment, West. J. Appl. For. 15: 15-26.

Boateng J. O., J.L. Heineman, J. McClarnon and L. Bedford. 2006. Twenty year responses of white spruce to mechanical site preparation and early chemical release in the boreal region of northeastern British Columbia. Can. J. For. Res. 36: 2386-2399.
Braumandl T.F. and M.P. Curran. 1992. A field guide for site identification and interpretation for the Nelson Forest Region. Land Manage. Handb. No. 20. BC Min. For., Nelson, BC.

Comeau, P.G., B.S. Biring and G.J. Harper. 1999. Conifer response to brushing treatments: A summary of British Columbia data. BC Min. of For., Res. Br., Exten. Note 41.

Comeau, P.G., B.S. Biring and G.J. Harper. 2000. Effectiveness of repeated manual cutting and glyphosate for release of Engelmann spruce from mixed-shrub herb vegetation. West. J. Appl. For. 15: 154-162.

Dampier, J.E.E., F.W. Bell, M. St-Amour, D.G. Pitt, D.G. and N.J. Luckai. 2006. Cutting versus herbicides: Tenth-year volume and release cost-effectiveness of sub-boreal conifer plantations. For. Chron. 82: 521-528.

Dubeau, D., L.G. DeBel and D. Imbeau. 2003. Integrated study of brushsaw operators in Quebec. Research Note, Tabled at XII World Forestry Congress by the Ministère des Ressources naturelles, de la Faune et des Parcs du Québec. Available at http://www.mrn. gouv.qc.ca/english/publications/forest/publications/dubeau-a.pdf [Accessed Jan. 8, 2009].

Ehrentaut G. and K. Branter. 1990. Vegetation management by manual and mechanical means in Alberta boreal forests. For. Chron. 66: 366-368.

Fu, S., F.W. Bell and H.Y.H. Chen. 2007. Long-term effects of intensive silvicultural practices on productivity, composition and structure of northern temperate and boreal plantations in Ontario, Canada. For. Ecol. Manage. 241: 115-126.

Haeussler, S., L. Bedford, A. Leduc, Y. Bergeron and J.M. Kranabetter. 2002. Silvicultural disturbance severity and plant communities of the southern Canadian boreal forest. Silva Fenn. 36: 307-327. Haeussler S., D. Coates and J. Mather. 1990. Autecology of common plants in British Columbia: a review. BC Min. For., Res. Br., FRDA Rep. 158. Victoria, BC.

Harper G. J., B.S. Biring and J. Heineman. 1997a. Mackay river herbicide trial: Conifer response 9 years post-treatment. BC Min. For., Res. Rep. 11. Victoria, BC.

Harper, G.J., P.G. Comeau and B.S. Biring. 2005. A comparison of herbicide and mulch mat treatments for reducing grass, herb and shrub competition in the BC Interior Douglas-fir zone - Ten year results. West. J. Appl. For. 20: 167-178.

Harper G.J., L.J. Herring and W.J. Hays-Byl. 1997b. Conifer and vegetation responses in the BWBSmw1 12 years after mechanical and herbicide site preparation. BC Min. For., Res. Br., Work. Pap. 29. Victoria, BC.

Harper, G.J., K. Polsson and J. Goudie. 2008. Modelling vegetation management treatments with the Tree and Stand Simulator. For. Chron. 84: 53-59.

Harper G., R. Whitehead and C.F. Thompson. 1998. A comparison of manual brushing treatments in the ICHdw at Redfish Creek: 10-year results from blocks 10-13. BC Min. For., Res. Br., Ext. Note 20. Victoria, BC.

Hart, D. and P.G. Comeau. 1992. Manual brushing for forest Vegetation Management in British Columbia: A review of current knowledge and information needs. BC Min. For., Land Manage. Rep. No. 77. Victoria, BC.

Heineman, J.L., S.W. Simard, D.L. Sachs and W.J. Mather. 2005. Chemical, grazing, and manual cutting treatments in mixed herb-shrub communities have no effect on interior spruce survival or growth in southern interior British Columbia. For. Ecol. Manag. 205: 359-374

Heineman, J.L., S.W. Simard, D.L. Sachs and W.J. Mather. 2007. Ten year response of Engelmann spruce and a high-elevation Ericaceous shrub community to manual cutting treatments in southern interior British Columbia. For. Ecol. Manag. 248: 153-162.

Lindgren, P.M.F. and T.P. Sullivan. 2001. Influence of alternative vegetation management treatments on conifer plantation attributes: abundance, species diversity and structural diversity. For. Ecol. Manage. 142: 163-182. 
Macadam, A. and R. Kabzems. 2006. Vegetation management improves early growth of white spruce more than mechanical site preparation treatments. N. J. Appl. For. 23: 35-46.

McDonald P.M., G.O. Fiddler, and H.R. Harrison. 1994. Repeated manual release in a young plantation: effect on Douglas-fir seedlings, hardwoods, shrubs, forbs, and grasses. USDA Forest Service, Pacific Southwest Research Station, Albany, CA., Res. Paper PSW-221.

McMinn, R.G. 1982. Ecology of site preparation to improve performance of planted white spruce in northern latitudes. In Forest regeneration at high latitudes: experiences from northern British Columbia. pp. 25-32. School of Agric. Land Resource. Manag. in cooperation with USDA For. Serv. Pacific Northwest For. Range Experimental Stat. Miscellaneous Rep. 82-1.

Miller D.L. 1985. Manual and mechanical methods of vegetation control - what works and what doesn't. In C.M. Baumgartner, R.J. Boyd, D.W. Breuer and D.L. Miller (eds.). Weed control for forest productivity in the interior west - Symposium proceedings, February 5-7, 1985, Spokane, Washington. pp. 55-60. Washington State Univ., Coop. Exten.

[BCMF] British Columbia Ministry of Forests. 1991. 1989/1990 Annual report, Victoria, BC. . 2000. 1999/2000 Annual Report, Victoria, BC.

Newton M., E.C. Cole, D.E. White and M.L. McCormack Jr. 1992. Young spruce-fir forests released by herbicides I. Response of hardwoods and shrubs. N. J. Appl. For. 9: 126-130.

Pitt, D.G. and F.W. Bell. 2005. Juvenile responses to conifer release alternatives on aspen-white spruce boreal mixedwood sites. Part 1: Stand structure and composition. For. Chron. 81: 538-547.
Pitt, D.G., M. Mihajlovich and L.M. Proudfoot. 2004. Juvenile stand responses and potential outcomes of conifer release efforts on Alberta's spruce-aspen mixedwood sites. For. Chron. 80: 583-597.

Rose R. and J.S. Ketchum. 2003. Interaction of initial seedling diameter, fertilization, and weed control on Douglas-fir growth over the first four years after planting. Ann. For. Sci. 60: 625-635.

Simard S.W., J.L. Heineman, W.J. Mather, D.L. Sachs and A. Vyse. 2001. Effects of operational brushing on conifers and plant communities in the southern interior of British Columbia, Results from PROBE 1991-2000 Protocol for Operational Brushing Evaluations. Res. Prog., Min. For., Land Manage. Handb. No 48.

Sullivan T.P., R.G. Wagner, D.G. Pitt, R.A. Lautenschlager and D.G. Chen. 1998. Changes in diversity of plant and small mammal communities after herbicide application in sub-boreal spruce forest. Can. J. For. Res. 28: 168-177.

Sutton R.F. 1995. White spruce establishment: initial fertilization, weed control, and irrigation evaluated after three decades. New Forests 9: 123-133.

Tatum, V.L. 2004. Toxicity, transport and fate of forest herbicides. Wildl. Soc. Bull. 32:1042-1048.

Wagner, R.G., K.M. Little, B. Richardson and K. Mcnabb. 2006. The role of vegetation management for enhancing productivity of the world's forests. Forestry 79: 57-79.

Whitehead R. and G.J. Harper. 1998. A comparison of four treatments for weeding Engelmann spruce plantations in the Interior Cedar Hemlock zone of British Columbia: ten years after treatment. Can. For. Serv., Pac. For. Cent., Victoria, BC. Inf. Rep. BC-X-379. 